\author{
G.K. Vassilina ${ }^{1,2}$, M.I. Tleubergenov ${ }^{1}$ \\ ${ }^{1}$ Institute of Mathematics and Mathematical Modeling, Almaty, Kazakhstan; \\ ${ }^{2}$ Almaty University of Energy and Communications, Almaty, Kazakhstan \\ (E-mail: v_gulmira@mail.ru)
}

\title{
On construction of the comparison function of program motion in probable statement
}

\begin{abstract}
In the class of ordinary differential equations the following modification of the inverse problem of differential systems was previously considered: to construct both a set of systems of differential equations and a set of comparison functions for the given program motion. In this article, the modification of the inverse problem is considered in Stochastic case. In this problem it is assumed that random perturbations are from the class of processes with independent increments. By the given program of motion, two sets are constructed: the set of first-order Itô stochastic differential equations and the set of comparison functions. It is proved that there is a stability in probability of the given program motion with respect to the constructed comparison functions. To solve the problem Lyapunov functions method is used. Using Lyapunov's second method makes it is possible to weaken the conditions imposed on the components of the constructed comparison functions, in contrast to the application of the Lyapunov characteristic numbers method for solving the inverse problem in the class of ordinary differential equations. The following cases are considered: 1) comparison functions obviously not depending on time; 2 ) the set of comparison vector functions depends on $y$ and $t$; 3 ) the set of comparison vector functions has the form $Q(\lambda, t$, where $\lambda(y, t)$ describes an analytically given program motion; 4) the set of comparison vector functions has the form $C(t) \lambda$.
\end{abstract}

Keywords: stochastic differential equations, inverse problems, stability in probability, comparison function, program motion, random process.

\section{Introduction}

At present, possible formulations of the inverse problems for differential systems have been known. General methods for solving these problems in the class of ordinary differential equations have been well developed in [1-11]. Generalization of these problems to the class of partial differential equations is investigated in [12-14]. In the theory of inverse problems of differential systems, an important requirement is the requirement of stability of the given properties of motion [5]. This requirement is related to the system's operability and its non-compliance with perturbations. Therefore, solving of stability problem of the program motion is essential for the further development of the qualitative theory of inverse problems of differential systems and constructing of the systems of program motion.

In the theory of stability, the possible perturbed motions of the material system are compared with the unperturbed motion with respect to the corresponding values of the given kinematic indicators of motion at each time instant $t \geq t_{0}$. It is assumed that the kinematic indicators of motion can be described by the vector function $Q(y, t)$, called the comparison function and given in some domain of the space $G\left(y_{1}, \ldots, y_{n}\right)$ of the change in the phase coordinates of the given system. The study of the stability of unperturbed motion is reduced to establishing the behavior of the difference of the values of this vector function respectively on possible perturbed motion and on unperturbed motion of system

$$
x=Q_{\text {perturbed motion }}-Q_{\text {unperturbed motion }},
$$

for all $t \geq t_{0}$. In problems of construction of stable systems, the desired system parameters and additional control forces are also determined from the conditions imposed on this difference. In the established formulations of the stability problems, the comparison functions are given. Also the unperturbed motion and the equations of motion of the material system are given. Thus, the solving of the stability problem is reduced to determining the stability conditions for the given motion of the system with respect to the given comparison functions. However in many problems of the theory of stability it is useful problem to construct the comparison functions with respect to which there is a stability of given properties of motion of the mechanical system. 
Galiullin A.S. posed the one of the inverse problems of dynamics namely the problem of construction of the set of comparison functions in the class of ordinary differential equations [1-3]:

It is required to construct the corresponding set of equations of motion for the material system

$$
\dot{y}=Y(y, t),
$$

by the given law of motion

$$
\Lambda: y=\varphi(t), y \in R^{n}, \varphi \in C^{1}\left\{t \geq t_{0}\right\} .
$$

Let the considering equations be the class of equations admitting the existence of the unique solution of the equation (1.1) with initial condition $\left.y\right|_{t=t_{0}}=\varphi\left(t_{0}\right),\left\{t_{0}, \varphi\left(t_{0}\right)\right\}$. And it is required to construct the set of n-dimensional vector functions $Q(y) . Q(y)$ is holomorphic vector functions in some $\varepsilon$-neighborhood $\Lambda_{\varepsilon}=\{\|y-\varphi(t)\|<\varepsilon\}$ of the integral manifold $\Lambda(t)$ (1.2) for all $t \geq t_{0}$. There is stability in the sense of Lyapunov in relation to the components of $Q(y)$.

The problem of construction of the set of comparison functions is solved by the method of characteristic Lyapunov numbers in [1-3]. The solution of this problem determines the set of kinematic indicators of motion (conditions imposed on them), with respect to which the given motion properties of the system are stable.

The set of equations of motion of the system is constructed in the form

$$
\dot{y}=\dot{\varphi}(t)+\Phi(y, t) .
$$

Here $\Phi(y, t)$ is some holomorphic vector function in the domain $\Lambda_{\varepsilon}$ for all $t \geq t_{0},\left.\Phi(y, t)\right|_{y=\varphi(t)}=0$. Further the equation of perturbed motion of the first approximation with respect to the vector function $Q(y)$ is compiled. The equation of perturbed motion is reduced to the system of linear differential equations by some linear transformation. It is required that the resulting system is correct and that its characteristic numbers are positive. Then, if the applied linear transformation is Lyapunov transformation, then there is stability of the given motion (1.2) with respect to the vector function $\mathrm{Q}(\mathrm{y})$. Following [2], the set of the required components of the vector functions $\mathrm{Q}(\mathrm{y})$ is determined from the conditions

$$
C, \dot{C} \text { are limited, } \operatorname{det} C^{-1} \neq 0 \text { for all } t \geq t_{0},
$$

here $C=\left\|\psi_{\nu}^{i}\right\|_{n}^{n}, \psi_{\nu}^{i}=\left.\frac{\partial Q_{i}(y)}{\partial y_{\nu}}\right|_{y=\varphi(t)}, i, \nu=1, \ldots, n$ and $C(t)$ is the Lyapunov transformation [15].

In the Preface of the J. Adomian's book «Stochastic Systems» (Moscow, 1987) the famous scientist Richard Bellman emphasizes: «It is very important to decide which model to build: deterministic model or stochastic model. Deterministic models are very useful. But stochastic models are more realistic. The difficulty is that the analysis of stochastic models by mathematical means is very complicated».

Stochastic differential equations of Itô type describe numerous and important in the application models of mechanical systems. These models take into account the effects of external random forces. In particular, models take into account the motion of an artificial satellite of the Earth under the action of the aerodynamic forces [16] or the fluctuation drift of the heavy gyroscope in a cardan suspension [17] and many others.

As an example showing the importance of taking into account random perturbations, we can cite the inverse problem of the dynamics of a spacecraft's flight. For example, the aerodynamic moments of a spacecraft always have random components [16] generated by density fluctuations of the planet's atmosphere. In addition, random changes in the moments of inertia cause thermoelastic vibrations of stabilizing rods, vibrations of liquids in cans, antennas and solar panels. And the study of the effect of random perturbations on the dynamics of the spacecraft is so important that ignoring these perturbations can significantly reduce the lifetime of the spacecraft [18].

Inverse problems in the class of stochastic differential systems are considered in [19-21]. Problems of stability in probability of the given program motion by Lyapunov function method are studied in [22, 23].

Let us consider the probabilistic formulation of the problem posed earlier in the class of ordinary differential equations [1-3], namely, with the additional assumption of the presence of random perturbations.

\section{Statement of the problem}

It is required to construct the corresponding set of equations of motion for the material system

$$
\dot{y}=Y(y, t)+\sigma(y, t) \dot{\xi}, \xi \in R^{k},
$$


by the given program of motion

$$
\Lambda: \lambda \equiv y-\varphi(t)=0, y \in R^{n}, \varphi \in C^{1},\|\varphi\| \leq l .
$$

Here $\xi(t)=\omega(t)+\int_{R^{n}} c(y) P(t, d y)$ is random process with independent increments; $\omega(t)$ is Wiener process; $P(t, A)$ is Poisson process as a function of $t$ and Poisson stochastic measure as a function of set $A ; c(y)$ is vector function mapping $R^{n}$ into the space of the process values $\xi(t)$ for all $t$.

Let the considering equations be the class of equations admitting the existence of a unique up to stochastic equivalence of solution of the equation (2.1) with initial condition $\left.y\right|_{t=t_{0}}=\varphi\left(t_{0}\right)$. It is also required to construct a set of $s$-dimensional vector functions $Q(y)$ so that there is stability in probability of the program motion $(2.2)$ with respect to $Q(y)$.

Following [3], the equation of perturbed motion of the material system, for which the given motion (2.2) is possible, is represented as

$$
\dot{\lambda}=A(\lambda ; y, t)+B(\lambda ; y, t) \dot{\xi}
$$

Here $A(\lambda ; y, t)$ is a vector function and $B(\lambda ; y, t)$ is a $n \times k$-dimentional Erugin type matrix such that $A(0 ; y, t) \equiv$ $0, B(0 ; y, t) \equiv 0$.

Let $\operatorname{LV}(\lambda(x, t), x, t)$ be generating operator of $\xi(t)[22]$.

In the future we need the following definitions:

Definition 1 [24]. A function $a(r)$ is called the function of Khan class $a(r) \in K$ if it is continuous and strictly increasing and satisfies the condition $a(0)=0$.

Definition 2 [25]. The program manifold (2.2) of the equation (2.1) is called $\rho$-stable in probability if

$$
\lim _{\rho\left(y_{0}, \Lambda\left(t_{0}\right)\right) \rightarrow 0} P_{x_{0}}\left\{\sup _{t>0} \rho\left(y^{y_{0}, t_{0}}(t), \Lambda(t)\right)>\varepsilon\right\}=0 .
$$

1 A set of vector functions $Q(y)$ that obviously not depending on time

Theorem 1. Let there exist a Lyapunov function $V(\lambda ; y, t)$ on the neighborhood $\Lambda_{\varepsilon}=\{\|y-\varphi(t)\|<\varepsilon\}$ of the integral manifold $\Lambda$ satisfying the conditions

$$
\begin{gathered}
a(\|\lambda\|) \leq V(\lambda ; y, t) \leq b(\|\lambda\|), a, b \in K, \\
L V \leq-c(\|\lambda\|), c \in K .
\end{gathered}
$$

Then the program motion $\lambda \equiv y-\varphi(t)=0$ of system (2.3) is asymptotically $\rho$ - stable in probability with respect to an arbitrary $s$ - dimensional vector function $Q(y)$, which is continuous on the neighborhood $\Lambda_{\varepsilon}$ for $1 \leq s \leq n$.

Proof. By definition of stability [3], we consider the difference $x=Q(y)-Q(\varphi(t))$. By the condition of the theorem, there is a Lyapunov function with properties (2.4), (2.5). This provides an asymptotically $\rho$-stability in probability of program motion $\lambda=0$ [22], i.e.

$$
\lim _{\rho\left(y_{0}, \Lambda\left(t_{0}\right)\right) \rightarrow 0} P_{y_{0}}\left\{\lim _{t \rightarrow \infty} \sup \rho\left(y^{y_{0}, t_{0}}(t), \Lambda(t)\right)=0\right\}=1 .
$$

And from the continuity of the vector function $Q(y)$ and conditions (2.6) we have

$$
\lim _{\rho\left(y_{0}, \Lambda\left(t_{0}\right)\right) \rightarrow 0} P_{y_{0}}\left\{\lim _{t \rightarrow \infty} \sup \left\|Q\left(y\left(t, t_{0}, y_{0}\right)\right)-Q(\varphi(t))\right\|=0\right\}=1 .
$$

This means that the motion $\lambda \equiv y-\varphi(t)=0$ of the system (2.3) is asymptotically stable with respect to the vector function $Q(y)$.

\section{$2 A$ set of vector functions $Q(y, t)$ depending on $y$ and $t$}

Theorem 2. Let there exist a Lyapunov function $V(\lambda ; y, t)$ on the neighborhood $\Lambda_{\varepsilon}$ of the integral manifold $\Lambda$ with properties (2.4), (2.5). 
Then the program motion $\lambda \equiv y-\varphi(t)=0$ of system (2.3) is asymptotically $\rho$ - stable in probability with respect to an arbitrary $s$ - dimensional vector function $Q(y, t)$, which is continuous in $y$ and $t$ and satisfying the condition

$$
\|x\| \leq \beta(\|\lambda\|), \beta \in K \text {. }
$$

Here $x=Q(y, t)-Q(\varphi(t), t)$.

Proof. The existence of a function $V(\lambda ; y, t)$ with properties $(2.4),(2.5)$ implies an asymptotical uniform in $\left\{t_{0}, y_{0}\right\} \rho$-stability in probability of motion $\lambda \equiv y-\varphi(t)=0[22]$, i.e.

$$
\lim _{\rho\left(y_{0}, \Lambda\left(t_{0}\right)\right) \rightarrow 0} P_{y_{0}}\left\{\lim _{t \rightarrow \infty} \sup \rho\left(y^{y_{0}, t_{0}}(t), \Lambda(t)\right)=0\right\}=1 .
$$

And we get from (2.6) and (2.7) that

$$
\lim _{\rho\left(y_{0}, \Lambda\left(t_{0}\right)\right) \rightarrow 0} P_{y_{0}}\left\{\lim _{t \rightarrow \infty} \sup \left\|Q\left(y\left(t, t_{0}, y_{0}\right), t\right)-Q(\varphi(t), t)\right\|=0\right\}=1 .
$$

Consequently, there is an asymptotic stability in probability of the motion $\lambda \equiv y-\varphi(t)=0$ of system $(2.3)$ with respect to the vector function $Q(y, t)$.

$$
3 \text { Program motion } \lambda(y, t)=0 \text { and a set of comparison vector functions } Q(\lambda, t)
$$

Let the program motion be given as

$$
\Lambda(t): \lambda(y, t)=0
$$

Here $\lambda \in R^{k}, y \in R^{n}, k \leq n$.

Suppose that it takes place $\operatorname{rang}\left\{\frac{\partial \lambda}{\partial y}\right\}=k$ for all $y \in \Lambda_{h}, t \geq t_{0}$ on a neighborhood $\Lambda_{h}(t) \in R^{n}$

$$
\Lambda_{h}(t):\|\lambda(y, t)\| \leq h, t \geq t_{0} .
$$

The set of equations of the perturbed motion for which the given program (2.8) is one of the possible ones, can be represented as

$$
\dot{\lambda}=A(\lambda ; y, t)+B(\lambda ; y, t) \dot{\xi}
$$

Here $A(\lambda ; y, t)$ is a vector function and $B(\lambda ; y, t)$ is a $n \times k$-dimentional Erugin type matrix such that $A(0 ; y, t) \equiv 0, B(0 ; y, t) \equiv 0$.

Consider the continuous $s$-dimensional vector functions $Q(\lambda, t)$ satisfying the condition

$$
\|x\| \leq \beta(\|\lambda\|), \beta \in K \text {. }
$$

Here $x=Q(\lambda(y, t))-Q(0, t), 1 \leq s \leq n$.

Theorem 3. Let there exist a Lyapunov function $V(\lambda ; y, t)$ on the neighborhood (2.9) of the integral manifold (2.8) satisfying the condition (2.4) and

$$
L V \leq-c(\|\lambda\|), c \in K
$$

Then the integral manifold (2.8) is asymptotically stable in probability with respect to an arbitrary $s$-dimensional vector function $Q(\lambda, t)$, which is continuous in $\lambda$ and $t$ and satisfying condition $(2.10)$ for $1 \leq s \leq n$.

The proof is similar to the proof of Theorem 2 .

\section{$4 A$ set of $n$-dimensional vector functions of the form $C(t) \lambda$}

Let the equation of perturbed motion (2.3) in the first approximation have the form

$$
\dot{\lambda}=A_{1}(t) \lambda+A_{2}(\lambda, t)+B \dot{\xi}
$$

Let us consider the Lyapunov function $V(\lambda)=(\lambda, \lambda)$ and $n$ - dimensional vector function $Q(y, t)=C(t) \lambda$. Here $\lambda \equiv y-\varphi(t)$. In this particular case $x=Q(y)-Q(\varphi(t))$ has the form

$$
x=C(t) \lambda \text {. }
$$


Also suppose that

1) the matrix $A_{1}^{T}(t)+A_{1}(t)$ is definitely negative and the vector function $A_{2}$ satisfies the condition $\left\|A_{2}\right\|=o(\|\lambda\|)$

2) the matrix

$$
C(t)=\left.\frac{\partial Q}{\partial y}\right|_{y=\varphi(t)} \text { is continuous and limited for all } t \geq t_{0}
$$

Then from properties 1), 2) and Theorem 2 the following theorem holds.

Theorem 4. Let $A_{1}(t)$ and $C(t)$ are continuous matrices such that conditions 1) and 2) hold. Then the motion $\lambda \equiv y-\varphi(t)=0$ of the system (2.3) is stable in probability with respect to an arbitrary vector functions $Q(y, t)=C(t) \lambda$.

Remark. In Theorem 4 instead of condition (1.4) the weaker condition (2.11) is required.

The work was supported by grant AP05131369 of Ministry of Education and Science of the Republic of Kazakhstan.

\section{References}

1 Галиуллин А.С. Задачи построения функций сравнения в теории устойчивости движения / А.С. Галиуллин // Дифференциальные уравнения. - 1974. - 10. - № 8. - С. 1527-1529.

2 Галиуллин А.С. Методы решения обратных задач динамики / А.С. Галиуллин. - М.: РУДН, 1986. - 224 c.

3 Галиуллин А.С. Избранные труды: [В 2 т.]. - Т. І. / А.С. Галиуллин. - М.: РУДН, 2009. - 462 с.

4 Мухарлямов Р.Г. О построении систем дифференциальных уравнений движения механических систем / Р.Г. Мухарлямов // Дифференциальные уравнения. - 2003. - 39. - № 3. - С. 343-353.

5 Mukharlyamov R.G. Reduction of dynamical equations for the systems with constraints to given structure / R.G. Mukharlyamov // Journal of Applied Mathematics and Mechanics. Elsevier. - 2007. - 71. P. 361-370.

6 Mukharlyamov R.G. Differential-algebraic equations of programmed motions of Lagrangian dynamical systems / R.G. Mukharlyamov // Mechanics of Solids. - 2011. - 46. - No. 4. - C. 534-543.

7 Mukharlyamov R.G. Control of system dynamics and constrains stabilization / R.G. Mukharlyamov, M.I. Tleubergenov // Communications in Computer and Information Science. - 2017. - 700. — P. 431442.

8 Zhumatov S.S. Asymptotic Stability of Implicit Differential Systems in the Vicinity of Program Manifold / S.S. Zhumatov // Ukrainian Mathematical Journal. - 2014. - 66. - No. 3. - P. 625-632.

9 Zhumatov S.S. Exponential Stability of a Program Manifold of Indirect Control Systems / S.S. Zhumatov // Ukrainian Mathematical Journal. - 2010. - 62. - No. 6. - P. 907-915.

10 Zhumatov S.S. Stability of a Program Manifold of Control Systems with Locally Quadratic Relations / S.S. Zhumatov // Ukrainian Mathematical Journal. - 2009. - 61. - No. 3. - P. 500-509.

11 Llibre J. Inverse Problems in Ordinary Differential Equations and Applications / J. Llibre, R. Ramirez. - Switzerland: Springer International Publishing, 2016. - 266 p.

12 Budochkina S.A. An operator equation with the second time derivative and Hamilton-admissible equations / S.A. Budochkina, V.M. Savchin // Doklady Mathematics. - 2016. - 94. - No. 2. - P. 487-489.

13 Savchin V.M. Nonclassical Hamiltons actions and the numerical performance of variational methods for some Dissipative Problems / V.M. Savchin, S.A. Budochkina // Communications in Computer and Information Science. - 2016. - 678. - P. 624-634.

14 Savchin V.M. Invariance of functional and related Euler-Lagrange equations / V.M. Savchin, S.A. Budochkina // Russian Mathematics. - 2017. - 61. - No. 2. - P. 49-54.

15 Демидович Б.П. Лекции по математической теории устойчивости / Б.П. Демидович. - М.: Наука, 1967. -472 c. 
16 Сагиров П. Стохастические методы в динамике спутников / П. Сагиров // Механика. Период. сб. пер. иностр. ст. - 1974. - № 5(147). - С. 28-47. - № 6(148). - С. 3-38.

17 Синицын И.Н. О флуктуациях гироскопа в кардановом подвесе / И.Н. Синицын // Изв. АН СССР. Механика твердого тела. - 1976. - № 3. - С. 23-31.

18 Демин В.Г. Движение искусственного спутника в нецентральном поле тяготения / В.Г. Демин. M., 1968. - 352 c.

19 Tleubergenov M.I. Main inverse problem for differential system with generate diffusion / M.I. Tleubergenov, G.T. Ibraeva // Ukrainian Mathematical Journal. - 2013. - 65. - 5. - P. 787-792.

20 Tleubergenov M.I. On the inverse stochastic reconstruction problem / M.I. Tleubergenov // Differential Equations. - 2014. - 50. - No. 2. - P. 274-278.

21 Tleubergenov M.I. Stochastic inverse problem with indirect control / M.I. Tleubergenov, G.T. Ibraeva // Differential Equations. - 2017. - 53. - No. 10. - P. 1387-1391.

22 Vassilina G.K. Solution of the Problem of Stochastic Stability of an Integral Manifold by the Second Liapunov Method / G.K. Vassilina, M.I. Tleubergenov // Ukrainian Mathematical Journal. — 2016. — 68. - No. 1. - P. 14-28.

23 Vasilina G.K. On the optimal stabilization of an integral manifold [Electronic resource] / G.K. Vassilina, M.I. Tleubergenov // Journal of Mathematical Sciences. - 2018. - 229. - No. 4. - P. 390-402. - Access mode: http://DOI 10.1007/s10958-018-3684-5.

24 Руш Н. Прямой метод Ляпунова в теории устойчивости / Н. Руш, П. Абетс, М. Лалуа. - М.: Мир, 1980. - 300 c.

25 Хасьминский Р.З. Устойчивость систем дифференциальных уравнений при случайных возмущениях их параметров / Р.З. Хасьминский. - М., 1969. - 368 с.

\title{
Г.Қ. Василина, М.Ы. Тілеубергенов
}

\section{Ықтималды жағдайдағы бағдарламалық қозғалыстың салыстыру фунциясының құрылуы туралы}

\begin{abstract}
Жай дифференциалдық теңдеулер класында бұрын дифференциалдық жүйелердің кері есебінің келесі түрленуі қарастырылды: дифференциалдық теңдеулер жүйелерінің жиынтығын және осы бағдарламаланған қозғалыс үшін салыстырмалы функциялар жиынтығын құру. Мақалада кері есептің бұл түрі ықтималды жағдайда зерттелді. Бұл есепте кездейсоқ түрткілер тәуелсіз өсімшелі кездейсоқ үдерістер класынан деп есептелді. Берілген қозғалыс бағдарламасына сәйкес, екі жиын құрылады: Итоның бірінші ретті стохастикалық дифференциалдық теңдеулер жиынтығы және салыстыру функциялары жиыны. Құрастырылған салыстыру функцияларына қатысты берілген бағдарламаланған қозғалыстың ықтималдық бойынша орнықтылығы бар екені дәлелденді. Бұл есепті шешу үшін Ляпунов функцияларының әдісі қолданылды. Ляпуновтың екінші әдісінің пайдалануы жай дифференциалдық теңдеулер класындағы кері есептерді шешу үшін қажет. Ляпуновтың сипаттаушы сандары әдісін қолданудан айырмашылығы алынған салыстыру функцияларының құраушыларына енгізілген шарттарды әлсіретуге мүмкіндік береді. Келесі жағдайлар қарастырылған, яғни салыстыру векторлық функциялары: 1) уақыттан нақты тәуелді емес; 2) жиынтығы $y$ және $t$-дан тәуелді; 3) жиынтығы $Q(\lambda, t)$ түрінде болады, мұнда $\lambda(y, t)=0$ аналитикалық түрде берілген бағдарламалық қозғалысты сипаттайды; 4) жиынтығы $C(t) \lambda$ түрінде болады. Қарастырылған жағдайларда құрылған салыстыру функциясына қатысты бағдарламалық қозғалыстың ықтималдық бойынша асимптотикалық орнықтылығының жеткілікті шарттары алынған.
\end{abstract}

Кілт сөздер: стохастикалық дифференциалдық теңдеулер, кері есептер, ықтималдық бойынша орнықтылық, салыстыру функциясы, бағдарламалық қозғалыс, кездейсоқ процесс. 
Г.К. Василина, М.И. Тлеубергенов

\title{
О построении функции сравнения программного движения в вероятностной постановке
}

\begin{abstract}
В классе обыкновенных дифференциальных уравнений ранее была рассмотрена следующая модификация обратной задачи дифференциальных систем: построить как множество систем дифференциальных уравнений, так и множество функций сравнения по заданному программному движению. В статье данная модификация обратной задачи рассмотрена в вероятностной постановке. В исследуемой задаче предположены случайные возмущения из класса процессов с независимыми приращениями. По заданной программе движения строятся два множества: множество стохастических дифференциальных уравнений Ито первого порядка и множество функций сравнения. Доказано, что имеет место устойчивость по вероятности заданного программного движения относительно построенных функций сравнения. Для решения поставленной задачи применен метод функций Ляпунова. Использование второго метода Ляпунова позволяет ослабить условия, накладываемые на составляющие построенных функций сравнения, в отличие от применения метода характеристичных чисел Ляпунова для решения обратной задачи в классе обыкновенных дифференциальных уравнений. Изучены случаи, когда множество вектор-функций сравнения 1$)$ не зависит явно от времени; 2) зависит от $y$ и $t ; 3)$ имеет вид $Q(\lambda, t)$, где $\lambda(y, t)=0$, описывает аналитически заданное программное движение; 4$)$ имеет вид $C(t) \lambda$. В рассмотренных случаях получены достаточные условия асимптотической устойчивости по вероятности программного движения относительно построенной функции сравнения.
\end{abstract}

Ключевые слова: стохастические дифференциальные уравнения, обратные задачи, устойчивость по вероятности, функция сравнения, программное движение, случайный процесс.

\section{References}

1 Galiullin, A.S. (1974). Zadachi postroieniia funktsii sravneniia v teorii ustoichivosti dvizheniia [Problems of construction of comparison functions in stability theory of the motion]. Differentsialnye uravneniia Differential equations, 10, 8, 1527-1529 [in Russian].

2 Galiullin, A.S. (1986). Metody resheniia obratnykh zadach dinamiki [Methods for solving inverse problems of dynamics]. Moscow: Nauka [in Russian].

3 Galiullin, A.S. (2009). Izbrannye trudy [Selected Works.] (Vol. 1, 2). Moscow: RUDN [in Russian].

4 Muharlyamov, R.G. (2003). O postroenii sistem differentsialnykh uravnenii dvizheniia mekhanicheskikh sistem [On construction of differential equations systems of motion of the mechanical systems]. Differentsialnye uravneniia - Differential equations, 39, 3, 343-353 [in Russian].

5 Mukharlyamov, R.G. (2007). Reduction of dynamical equations for the systems with constraints to given structure. Journal of Applied Mathematics and Mechanics, 71, Elsevier, 361-370.

6 Mukharlyamov, R.G. (2011). Differential-algebraic equations of programmed motions of Lagrangian dynamical systems. Mechanics of Solids, 46, 4, 534-543.

7 Mukharlyamov, R.G., \& Tleubergenov M.I. (2017) Control of system dynamics and constrains stabilization. Communications in Computer and Information Science, 700, 431-442.

8 Zhumatov, S.S. (2014). Asymptotic Stability of Implicit Differential Systems in the Vicinity of Program Manifold. Ukrainian Mathematical Journal, 66, 3, 625-632.

9 Zhumatov, S.S. (2010). Exponential Stability of a Program Manifold of Indirect Control Systems. Ukrainian Mathematical Journal, 62, 6, 907-915.

10 Zhumatov, S.S. (2009) Stability of a Program Manifold of Control Systems with Locally Quadratic Relations. Ukrainian Mathematical Journal, 61, 3, 500-509.

11 Llibre J., \& Ramirez, R. (2016). Inverse Problems in Ordinary Differential Equations and Applications. Springer International Publishing Switzerland.

12 Budochkina, S.A., \& Savchin, V.M. (2016). An operator equation with the second time derivative and Hamilton-admissible equations. Doklady Mathematics, 94, 2, 487-489. 
13 Savchin, V.M., \& Budochkina, S.A. (2016). Nonclassical Hamiltons actions and the numerical performance of variational methods for some Dissipative Problems. Communications in Computer and Information Science, 678, 624-634.

14 Savchin, V.M., \& Budochkina, S.A. (2017). Invariance of functional and related Euler-Lagrange equations. Russian Mathematics, 61, 2, 49-54.

15 Demidovich, B.P. (1967). Lektsii po matematicheskoi teorii ustoichivosti [Lectures on mathematical theory of stability]. Moscow: Nauka [in Russian].

16 Sagirov, P. (1974). Stokhasticheskiie metody v dinamike sputnikov [Stochastic methods in satellite dynamics] Mekhanika. Periodicheskii sbornik perevodov inostrannykh statei - Mechanics. Periodic collection of translation of foreign articles, 5(147), 28-47, No. 6(148), 3-38. Moscow [in Russian].

17 Sinitsyn, I.N. (1976). O fluktuatsiiakh hiroskopa v kardanovom podvese [On fluctuations of the gyroscope in a cardan suspension]. Izvestiia AN SSSR. Mekhanika tverdoho tela - News of Academy of Sciences of the USSR. Solid mechanics, 3, 23-31. Moscow [in Russian].

18 Demin, V.G. (1968). Dvizhenie iskusstvennoho sputnika $v$ netsentralnom pole tiahoteniia [Motion of an artificial satellite in a non-Central gravitational field]. Moscow: Nauka [in Russian].

19 Tleubergenov, M.I., \& Ibraeva G.T. (2013). Main inverse problem for differential system with generate diffusion Ukrainian Mathematical Journal, 65, 5, 787-792.

20 Tleubergenov, M.I. (2014). On the inverse stochastic reconstruction problem. Differential Equations, 50, 2, 274-278.

21 Tleubergenov, M.I., \& Ibraeva, G.T. (2017). Stochastic inverse problem with indirect control. Differential Equations, 53, 10, 1387-1391.

22 Vassilina, G.K., \& Tleubergenov, M.I. (2016). Solution of the Problem of Stochastic Stability of an Integral Manifold by the Second Liapunov Method. Ukrainian Mathematical Journal, 68, 1, 14-28.

23 Vasilina, G.K., \& Tleubergenov, M.I. (2018). On the optimal stabilization of an integral manifold. Journal of Mathematical Sciences, 229, 4, 390-402. Retrieved from http://DOI 10.1007/s10958-018-3684-5.

24 Rusch, N., Abets, P., \& Lalua, M. (1980). Priamoi metod Liapunova v teorii ustoichivosti [Lyapunov's direct method in stability theory]. Moscow: Mir [in Russian].

25 Khas'minskii, R.Z. (1969). Ustoichivost sistem differentsialnykh uravnenii pri sluchainykh vozmushcheniiakh ikh parametrov [Stability of differential equations systems with random perturbations of their parameters]. Moscow: Nauka [in Russian]. 